\title{
MDR modulation in colorectal adenocarcinoma cell lines: kinetic studies using ${ }^{99 \mathrm{~m}} \mathrm{Tc}$-sestamibi
}

\author{
João Casalta-Lopes ${ }^{1 *}$, A Margarida Abrantes ${ }^{1,3}$, Joana Rio ${ }^{1}$, Mafalda Laranjo ${ }^{1,3}$, Bárbara Oliveiros ${ }^{1}$, \\ A Cristina Gonçalves ${ }^{2,3}$, Ana B Sarmento-Ribeiro ${ }^{2,3}$, M Filomena Botelho ${ }^{1,3}$ \\ From 16th International Charles Heidelberger Symposium on Cancer Research \\ Coimbra, Portugal. 26-28 September 2010
}

Multidrug resistance (MDR) represents one of the major setbacks to chemotherapy and can occur due to the overexpression of efflux pumps as P-glycoprotein (Pgp), multiple resistance-related protein 1 (MRP1) and lung resistance-related protein (LRP). Verapamil, a substrate for Pgp, modulates its activity. L-buthionine-sulfoximine (BSO) can be used as blocker for MRP1. In this study we aim to compare transport kinetics for sensitive and resistant human colorectal adenocarcinoma cell lines, in the presence and absence of verapamil and BSO, through ${ }^{99 \mathrm{~m}} \mathrm{Tc}$-Sestamibi.

Pgp, MRP1 and LRP expression was evaluated in resistant (LS1034) and sensitive (WiDr) human colorectal adenocarcinoma cell lines using flow-cytometry. Western blot was also used to analyze Pgp expression. Cellular transport kinetics was assessed in the presence and absence of verapamil and BSO. Retention studies were performed after cell incubation with those drugs, for different time intervals (10 and 60 minutes) and concentrations $(10,25,50$ and $100 \mu \mathrm{M})$, using ${ }^{99 \mathrm{~m}} \mathrm{Tc}$-Sestamibi.

Pgp expression was significantly higher $(\mathrm{p}<0.05)$ in resistant cells, although LRP was also expressed. Western blotting analysis confirmed flow-cytometry results. ${ }^{99 \mathrm{~m}} \mathrm{Tc}$-Sestamibi retention percentage was significantly higher $(\mathrm{p}<0.05)$ in the resistant cell line for all time-points considered. In resistant cells incubated with MDR modulators there were statistically significant differences $(p<0.05)$ among the modulators used but only for the first minutes after incubation with the radiotracer.
The data obtained suggest that these modulators should be used immediately before the cytotoxic drugs are administrated.

\section{Author details}

'Biophysics/Biomathematics Institute (IBILI), Faculty of Medicine, University of Coimbra, Coimbra, Portugal. ${ }^{2}$ Biochemistry Institute, Faculty of Medicine, University of Coimbra, Coimbra, Portugal. ${ }^{3}$ CIMAGO, Faculty of Medicine, University of Coimbra, Coimbra, Portugal.

Published: 24 September 2010

\section{doi:}

Cite this article as: Casalta-Lopes et al:: MDR modulation in colorectal adenocarcinoma cell lines: kinetic studies using ${ }^{99 \mathrm{~m}} \mathrm{Tc}$-sestamibi. $B M C$ Proceedings 2010 4(Suppl 2):P22.

\footnotetext{
* Correspondence: jelopes@fmed.uc.pt

'Biophysics/Biomathematics Institute (IBILI), Faculty of Medicine, University of Coimbra, Coimbra, Portugal

Full list of author information is available at the end of the article
}

Submit your next manuscript to BioMed Central and take full advantage of:

- Convenient online submission

- Thorough peer review

- No space constraints or color figure charges

- Immediate publication on acceptance

- Inclusion in PubMled, CAS, Scopus and Google Scholar

- Research which is freely available for redistribution

Submit your manuscript at www.biomedcentral.com/submit
Biomed Central 